\title{
2012 年度秋季「賛助会員の会」開催報告
}

秋季大会会期中（於：九州工業大学）の9月 15 日, 「賛 助会員の会」第 5 回総会, 第 4 回ニューテクノフォーラム (NTF) 等の各種行事が開催された。総会，NTFに続き 昼食懇談会, および 2012 年度第 5 回運営委員会を開催し 今後のさらなる活動の活発化に向けて議事が進められた。 以下，概略を報告する。

\section{1. ま えがき}

賛助会員相互および学会幹部らとの, 交流の定常的機会 の提供を目的に設立された「賛助会員の会」が企画主催し た第 4 回ニューテクノフォーラム, それに先立つ第 5 回総 会, NTF 後の昼食懇談会, 2012 年度第 5 回運営委員会が おのおの開催され，滞りなく終了した.

\section{2. 第 5 回 総 会}

2012 年 9 月 15 日（土） $9: 00 \sim 9: 30$, 九州工業大学戸 畑キャンパス講堂にて, 26 名の参加者を得て第 5 回総会 が開催された，渋川会長の挨拶に続き，北嶋運営委員長よ り本日の全体開催スケジュール,「賛助会員の会」活動状 況について報告があった，今後の計画と参画への扮願い， 技術賞，技術奨励賞およびフェロー，アフィリエイトへの 積極的な応募要請があった。

\section{3. 第 4 回ニューテクノフォーラム}

第 5 回総会に引き続き, 第 4 回ニューテクノフォーラム が「新興国ボリュームゾーンに向けた工作機械戦略と技術 課題」をテーマに開催された. 日本工業大学 専門職大学 院の横田悦二郎教授の「アジアにおけるモノづくり産業の 現状と将来〜工作機械市場を中心に〜」と題した基調講演 に続き, (株) 森精機製作所 藤嶋 誠氏の「森精機製作所の グローバル戦略」, THK(株) 星出 薰氏の「直動システム の最新技術と新興国市場に向けた取組み」，ヤマザキマザ ック (株) 高田芳治氏の「最近の工作機械動向」, サンドビ ック(株) 鈴木 周氏の「サンドビックのアジア成長戦略〜

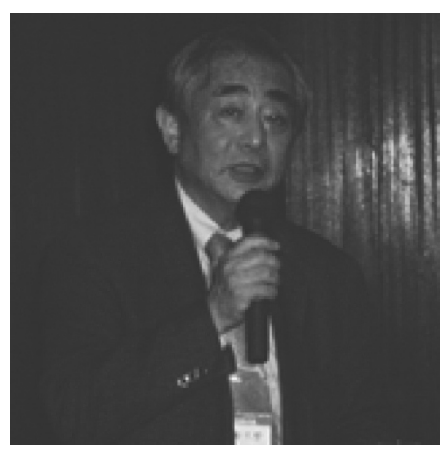

図 1 北嶋委員長

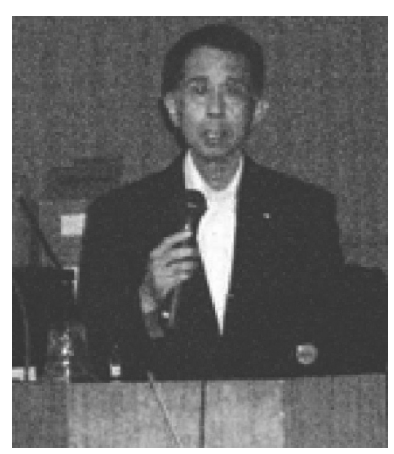

図2 渋川会長挨拶

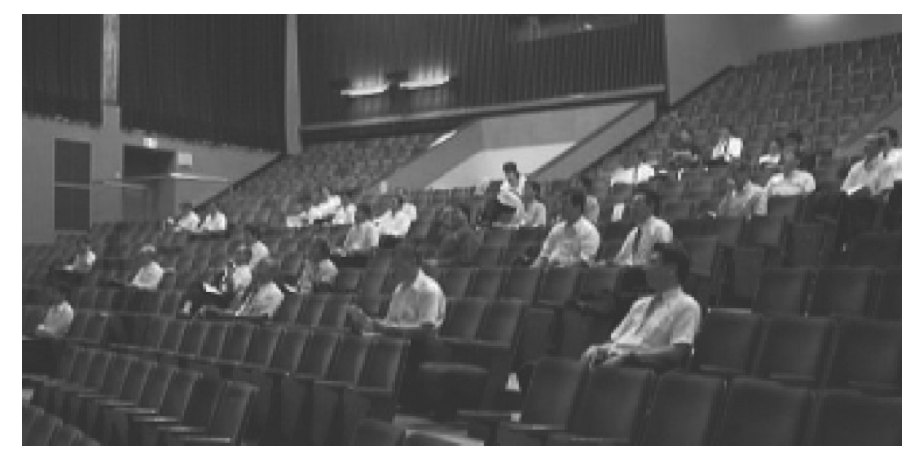

図 3 総会の様子
アジアの現状と展望〜」とおのおの題する話題提供が行わ れた。 パネルディスカッションではボリュームゾーンを狙 う上での核となる技術や産学連携について熱のこもった議 論が進められ盛会のうちに終了した。

\section{4. 昼 食愳 談会}

第 4 回ニューテクノフォーラム終了後, 生協食堂に会場 を移して, パネルディスカッション・講演メンバー, 参加 者等々, 産学関係者を交えた昼食懇談会を開催した。台風 の接近で外は大雨の様相であったが, 会場内では軽食を取 りながら賛助会員相互および学会関倸者が, 親睦を深めな がら意義ある 1 時間を過ごした後, 散会した。

\section{5. 第 5 回運営委員会}

同日 $13: 00$ より, 第 5 回運営委員会が開催された。北 嶋運営委員長の挨拶に続き，今後の NTF 開催テーマにつ いて, 次回以降 4 回分を見据えたテーマ案の議論を行 った。

各委員に実施した事前のアンケート集計結果「NTFの 今後の課題」を参考にして, 各委員間の意見交換を行っ た. その中で有力な意見として, 前向きな話題で活力が出 る次のようなテーマが候補に上がった。 (1)日本人の巧みに ついて(2)強い産業, 世界のトップを走る企業による企業戦 略/運営について, また, 関連企業の裾野が広く参加者を 集めやすい(3)自動車関連産業の現状についてなどキキーワ 一ドとしては, 人材育成, 技術/技能の伝承, 戦略として 具体的なテーマ選定を行うことにした。

第 5 回（2013 年春季大会）は技術/技能の伝承をテーマ 案とし, 第 6 回は「世界トップシェア企業/オンリーワン 商品を持つ企業」をテーマとした。その詳細や第 7 回, 第 8 回テーマについては, 運営委員会にて意見集約を行って いくこととした. 


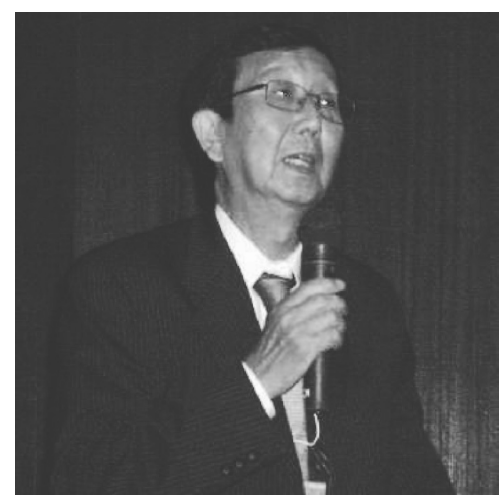

図 $4 \mathrm{NTF}$ 基調講演の横田氏

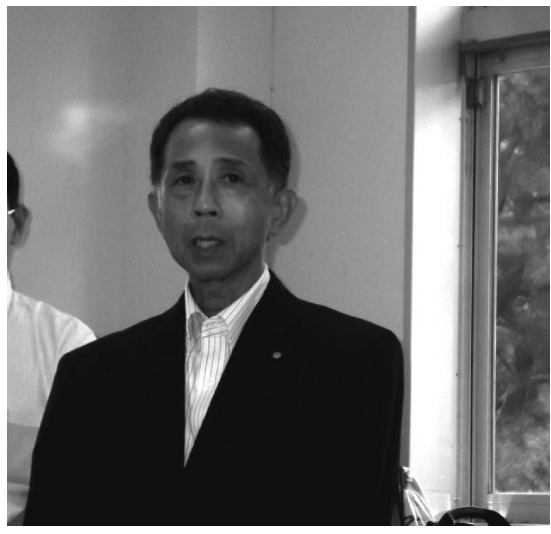

図 6 渋川会長の挨拶（昼食懇談会）

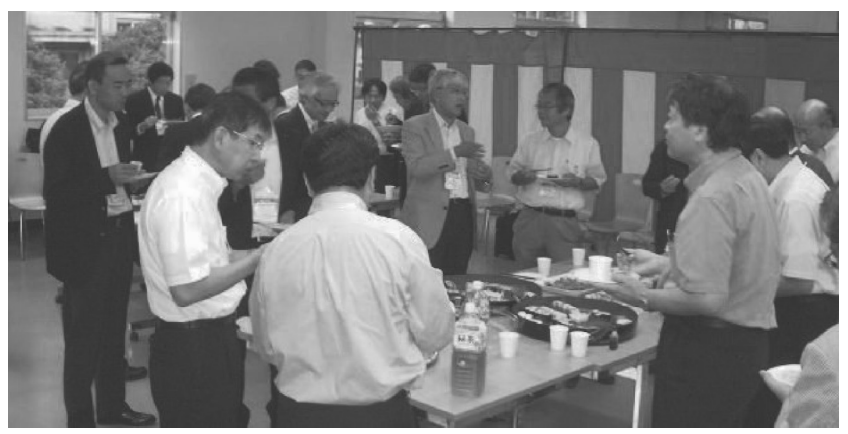

図 7 昼食懇談会の様子

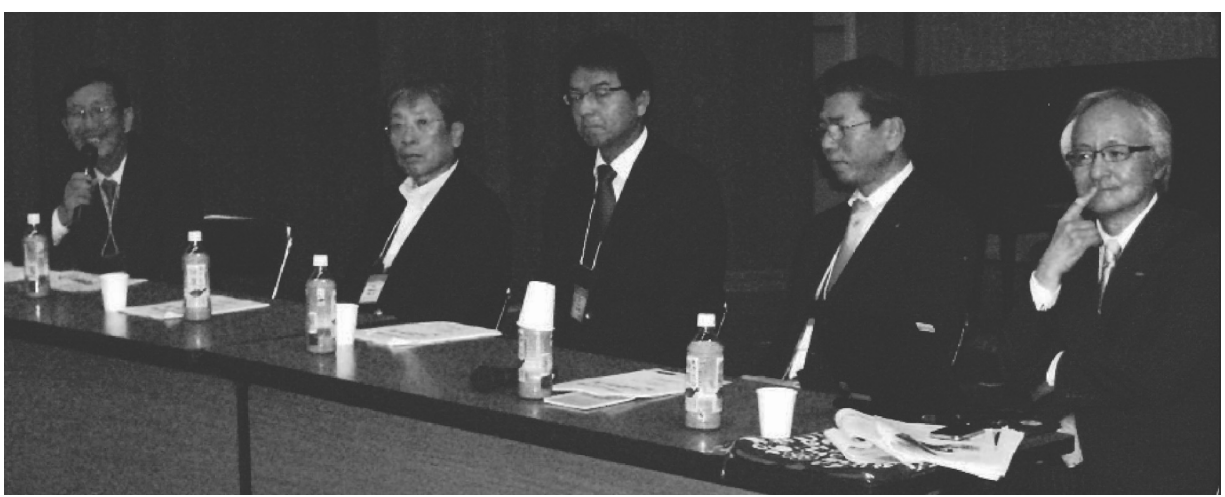

図 5 NTF パネルデイスカッションの様子

\section{6. ま と め}

賛助会員の会 ニューテクノフォーラム抽び懇談会 が, 各分野での研究開発, 実用化レベルでの情報共有化あ るいは新たなシーズ・ニーズの方向性を提供する場として 発展していくよう, また, 精密工学会の発展のために各会 員企業の積極的な参加, ならびに支援や助言をお願いし たい. 